\title{
The Role of Porphyromonas gingivalis Virulence Factors in Periodontitis Immunopathogenesis
}

\author{
(Peran Faktor Virulensi Porphyromonas Gingivalis pada Imunopatogenesis Periodontitis) \\ Tienneke Riana Septiwidyati, Endang Winiati Bachtiar \\ Department of Oral Biology, Faculty of Dentistry, Universitas Indonesia, Jakarta, Indonesia, \\ Email: endang04@ui.ac.id
}

\begin{abstract}
Porphyromonas gingivalis is an anaerobic Gram-negative bacteria, often associated with the pathogenesis of periodontitis. Periodontitis is a chronic inflammation characterized by damage to the supporting tissues of the tooth. Porphyromonas gingivalis locally can invade periodontal tissue and avoid host defence mechanisms. Porphyromonas gingivalis have virulence factors that can interfere with host immune response and cause inflammation at host tissue. The aim of this article is to provide an overview of the role of Porphyromonas gingivalis virulence factors such as capsules, fimbriae, lipopolysaccharides, and gingipain in the pathogenesis of periodontitis. The data sources were taken from PubMed and Google Scholar within 10 years. The role of Porphyromonas gingivalis capsule is to suppress the host's immune response to bacteria by reducing phagocytosis so the bacteria can survive. The roles of Porphyromonas gingivalis fimbriaeare to facilitate adhesion and invasion of bacteria to host cells so the damage will occur in the periodontal tissue. One of the roles of Porphyromoas gingivalis lipopolysaccharide is to disrupt the host immune system by disrupting the distribution of leukocytes around bacterial colonization so the bacteria can survive. The role of the Porphyromonas gingivalis gingipain is to suppress inflammatory cytokines thereby reducing the host's response by manipulating the complement system and disrupting the response of $\mathrm{T}$ cells. Porphyromonas gingivalis expresses several virulence factors involved in the colonization of subgingival plaque, modulates the immune response of host cells, and damages the host tissue directly so it can cause periodontitis.
\end{abstract}

Keywords: Porphyromonas gingivalis, Virulence Factors, Immunopathogenesis, Periodontitis.

\begin{abstract}
Abstrak
Porphyromonas gingivalis adalah bakteri Gram-negatif anaerob yang sering dihubungkan dengan patogenesis periodontitis. Periodontitis adalah inflamasi kronis yang ditandai dengan kerusakan pada jaringan pendukung gigi. Porphyromonas gingivalis secara lokal dapat menyerang jaringan periodontal dan menghindari mekanisme pertahanan inang. Porphyromonas gingivalis memiliki faktor virulensi yang dapat mengganggu respon imun inang dan menyebabkan inflamasi pada inang. Tujuan penulisan artikel ini adalah untuk memberikan gambaran peran faktor virulensi Porphyromonas gingivalis seperti kapsul, fimbriae, lipopolisakarida, dan gingipain dalam patogenesis periodontitis. Sumber data diambil dari PubMed dan Google Cendekia dalam kurun waktu 10 tahun.Peran kapsul Porphyromonas gingivalis sebagai salah satu faktor virulensi adalah menekan respon imun inang terhadap bakteri dengan mengurangi fagositosis sehingga bakteri dapat bertahan hidup. Peran fimbriae Porphyromonas gingivalis adalah untuk memfasilitasi adhesi dan invasi bakteri ke sel inang sehingga akan terjadi kerusakan pada jaringan periodontal. Salah satu peran lipopolisakarida Porphyromoas gingivalis adalah dengan mengganggu sistem imun inang dengan mengganggu distribusi leukosit sekitar bakteri kolonisasi, sehingga bakteri dapat bertahan hidup. Peran gingipain Porphyromonas gingivalis adalah menekan sitokin inflamasi sehingga mengurangi respon inang dengan memanipulasi sistem komplemen dan mengganggu respon sel T. Porphyromonas gingivalis memiliki beberapa faktor virulensi yang terlibat dalam kolonisasi pada plak subgingiva, memodulasi respons imun sel inang, dan merusak jaringan host secara langsung sehingga dapat menyebabkan periodontitis.
\end{abstract}

Kata kunci: Porphyromonas gingivalis, Faktor Virulensi, Imunopatogenesis, Periodontitis. 


\section{INTRODUCTION}

Periodontitis is a chronic inflammatory disease characterized by damages to the supporting tissues of the teeth, including the gingiva, periodontal ligament, and alveolar bone. When inflammation becomes chronic, the adaptive immune response will be active by involving cellular and non-cellular mechanisms of acquired immunity. So periodontitis can be regarded as an immune-inflammatory disease. ${ }^{1-4}$ The prevalence of periodontal disease globally is between $20-50 \%{ }^{5,6}$

Some oral bacteria have a role in the pathogennesis of periodontitis for example, Porphyromonas gingivalis, Treponema denticola, and Tannerella forsythia, so they are referred as periodontopathic bacteria. ${ }^{7-9}$ Among these three bacteria, $P$. gingivalis is the most common bacterium associated with periodontitis. ${ }^{10}$

The pathogenesis of periodontitis begins with the formation of subgingival bacterial biofilms. Bacterial biofilms in subgingival potentially disrupt the host immune. Host response to bacteria is the main mechanism in periodontitis. ${ }^{1112}$

The existence of $P$. gingivalis in periodontal pockets was reported to influence the development of periodontitis and the finding of $P$. gingivalis was positively correlated with pocket depth. ${ }^{13}$ Several experimental in animal models were reported that $P$. gingivalis to be able to induce inflammatory responses and cause bone loss alveolar. ${ }^{7}$ Potential virulence factors of $P$. gingivalis are capsules, fimbriae, lipopolysaccharide, and cysteine proteinases or gingipain. ${ }^{1314}$ The dominant $P$. gingivalis virulence factor found as a cause of periodontitis can be used as a vaccine subunit to prevent periodontitis. This paper provides a better understanding of the characteristics of $P$. gingivalis virulence factors and cellular or molecular interactions between $P$. gingivalis and the host, so that prevention and therapy in controlling the development of periodontitis can be addressed appropriately. The aim of this article is to provide an overview of the role of $P$. gingivalis virulence factors such as capsules, fimbriae, lipopolysaccharides, and gingipain in the pathogenesis of periodontitis to improving understanding which is the significance of the study.

Periodontal disease is a pathological state of periodontium structure. ${ }^{9}$ Gingivitis is inflammation of the gingival tissue that is characterized by redness, swellling, and bleeding tissue, caused by dental plaque. Alveolar bone and periodontal ligament are not involved in gingivitis, so there is no influence on the attachment of the teeth. ${ }^{9}$ Periodontitis refers to inflammation plaque-induced periodontal tissue that leads to damage to the periodontal ligament and alveolar bone. Periodontitis causes the formation of the periodontal pocket, the main clinical sign of periodontitis. The pe-riodontal pocket is a place for bacterial coloniza-tion. ${ }^{9}$ Another characteristic feature of periodon-titis is the damage of alveolar bone due to the activation of osteoclastogenesis. This is irrever-sible and causes loss of tooth support. ${ }^{15}$

Periodontitis is caused by interactions between species of bacteria that can cause this disease. Porphyromonas gingivalis, Actinobacillus actinomycetemcomitans, Treponema denticola, Tannerella forsythia, Prevotella intermedia, Fusobacterium nucleatum, and Campylobacter spp. found in this disease and affected the development of the disease. ${ }^{1617}$ From subgingival plaque periodontitis patients, $P$. gingivalis was found $85.75 \% .{ }^{918} P$. gingivalis exposure to subgingival non-human primates and mice caused bone loss. ${ }^{7}$

$P$. gingivalis is non-acetyl, non-motile, and black pigmented Gram-negative bacteria, need anaerobic conditions to grow and need the availability of heme and vitamin $\mathrm{K}$ in its environment. $P$. gingivalis is also an asaccharolytic bacteria, which uses amino acids as an energy source, it is useful for living in deep periodontal pockets, where there is a little sugar for energy sources. On subgingival biofilm, $P$. gingivalis is a secondary colony so that it is found near and interacts with gingival tissue. This is due to $P$. gingivalis is an anaerobic obligate bacteria. ${ }^{1920}$ P.gingivalis forms a black pigmented colony on the blood agar plate, this is related to heme aggregation on the cell surface because these bacteria need iron as a nutrient. ${ }^{13}$

Bacteria must attach on teeth or mucosal surface to survive in the oral cavity. ${ }^{21}$ Adhesion properties are very important to provide resistance from the salivary flow. The interaction between adhesin on the bacterial surface and receptors on the oral surface causes adhesion. Bacterial adhesin is a component of cell structure, such as capsules. ${ }^{9}$

The study said that increased resistance to phagocytosis was correlated with increased capsulation. ${ }^{10}$ Other research reveals that $P$. gingivalis strains W50 and W83 which have thicker capsules, decreased leukocyte production than strain 376. This suggests that the differences in bacteria strains may be caused by differences in capsular structure. ${ }^{9}$ Recent findings suggest that $P$. gingivalis capsules can induced host responses with reduced cytokines IL-1, IL-6, and IL-8 by fibroblasts. ${ }^{22}$ Regulation of adaptive immune responses has been shown to decrease against encapsulated $P$. gingivalis. IgA response was signifycantly in- 
creased in animals exposed to non-encapsulated 381 strains. These results showed that bacteria capsule can avoid adaptive and humoral immunity responses. ${ }^{10}$

Bacterial capsules affect the maturation of dendritic cells because capsules protect the structure of the outermost bacteria that interacts with dendritic cells. Research shows that the non-encapsulated P.gingivalis $\mathrm{PgC}$ strain can induce dendritic cell maturation faster than the encapsulated W50 strain. These studies showed that $P$. gingivalis capsules inhibit host response, it can cause bacteria to escape the host immune defence so they can survive and grow. ${ }^{10}$

$P$. gingivalis fimbriae is a thin, stringy cell surface protrusion that facilitates adhesion to host cells and other bacteria. With fimbriae, $P$. gingivalis can adhesion to early bacterial colonies and plays a role in the development of biofilms. Types of fimbriae are I (major) type fimbriae called fimbrillin or FimA coded by the fimA gene have an important role in colonization and invasion, II (minor) type fimbriae called Mfa subunit protein coded by the mfal gene. ${ }^{23,24}$ The special role of fimbriae is to induce bone destruction in the experimental periodontitis model. ${ }^{9}$

$P$. gingivalis FimA and Mfa1 are strong inducers of pro-inflammatory molecules. $P$. gingivalis FimA is reported to induce inflammatory molecules such as TNF $\alpha$ MCP-1, IL-6, IL-8, IL-1 $\beta$. P. gingivalis Mfa1 is reported to induce inflammatory molecules, such as IL-6, IL-1 $\beta$, and TNF $\alpha^{7}$

When fimbria interacts with TLR2/ CD14, the proadhesive pathway is initiated. This causes the induction of Rac1/PI3K, which activates CR3 so that affinity is increased. ${ }^{25-27}$ Activation of the TLR2 signalling pathway in and out by fimbriae leads to increased adhesion of monocytes that depend on CR3 and transendothelial migration. $P$. gingivalis will bind to CR3, enter the cell, and inhibit IL-12p70, which consists of subunits $\mathrm{p} 35$ and $\mathrm{p} 40$. When $P$. gingivalis fimbriae interact with CR3, which leads to outside-in signaling, it affects ERK1/2, thereby reducing the regulation of IL-12 p35 and IL-12 p40, this causes inhibition of IL-12p70 production. In addition, the stimulation of TLR2 by $P$. gingivalis will induce NF$\mathrm{kB}$ activation (Figure 1). ${ }^{28,29}$ Thus, CR3, which is exploited by $P$. gingivalis can interfere with the phagocytic process of bacteria mediated by IL-12, thereby increasing its viability and capacity to cause periodontitis. IL-12p70 acts to activate T and NK cells that produce IFN- $\gamma$, which functions to activate the bactericidal function in macrophages. ${ }^{30}$

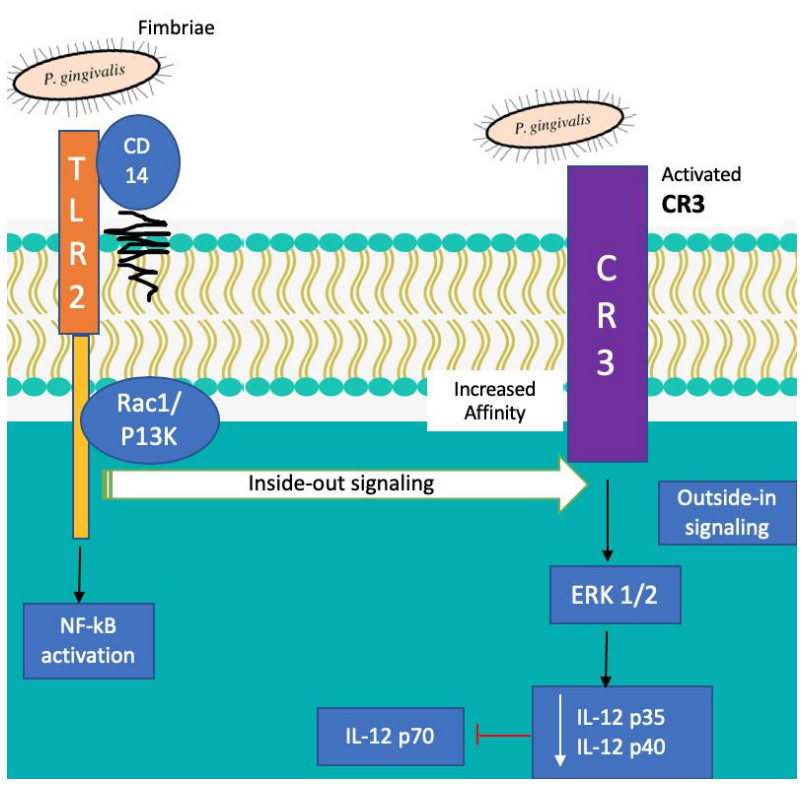

Figure 1. Interaction $P$. gingivalis with TLR2 and CR2 to undermine innate immunity ${ }^{29}$

Lipopolysaccharides (LPS) are relatively large molecules with a size of at least $10 \mathrm{kDa}$. Bacterial lipopolysaccharides consist of distal polysaccharides (O-antigens), core oligosaccharides and hydrophobic domains known as lipid A or endotoxins as contained..$^{31}$ Lipid A is the lipopolysaccharides biological active region, caused deregulation innate immune that interacts with toll-like receptors (TLR) 2 and $4 .{ }^{9}$

Bacteria lipopolysaccharides have function to maintain the integrity and structure of cells, controlling the entry of toxic chemicals and hydrophobic molecules. Many studies have reported the ability of lipopolysaccharides $P$. gingivalis to induce inflammation and disrupt the host bone remodelling process. ${ }^{9}$

The role of $P$. gingivalis lipopolysaccharides is to interfere with the innate host through leukocytes distribution around bacterial colonization. Also, lipopolysaccharides reduce gingival epithetlial cell's ability to secrete IL-8, so the activation of basophils, eosinophils, and neutrophils are affected. Without an effective innate immune defence, the number of periodontal bacteria can increase rapidly. The presence of bacterial colonies in periodontal tissue and the failure of the host defence system is an etiology observed from periodontal disease. In addition to inducing the synthesis of proinflammatory cytokines, $P$. gingivalis lipopolysaccharides inhibit osteoblastic differentiation and mineralization in periodontal ligament stem cells that have a role in tissue regeneration. ${ }^{9}$ 
Gingival fibroblasts are reported to induce pro-inflammatory cytokines, such as TNF $\alpha$, IL-8, IL-1, and IL-6 after exposed by $P$. gingivalis lipopolysaccharides. The interaction of $P$. gingivalis lipopolysaccharide and TLR on fibroblasts activates these cells to induce proinflammatory cytokines. It was also reported that $P$. gingivalis lipopolysaccharide induces the secretion of IL- 8 and IL-1 $\beta$ from human monocyte cells. Immunological dysregulation is caused by heterogeneity in the structure of lipopolysaccharides thus inducing an opposite immune response. ${ }^{7,32}$

Gingipain is a cysteine proteinase secreted by $P$. gingivalis and also accounts for $85 \%$ of the total proteolytic activity of $P$. gingivalis. Based on the specificity of the substrate, it is divided into specific arginine gingipain $(\operatorname{Arg}-\mathrm{X})$ and lysine (Lys-X). Arginine Gingipain can decrease extracellular matrix components, including complement factors, cytokines, immunoglobulins, and integrin-fibronectin binding. There are two types of arginine gingipain, RgpA, contains adhesion and proteolytic domains, and $\operatorname{RgpB}$ only contains proteolytic domains. There is one type of lysine gingipain, Kgp, which contains adhesion and proteolytic. Between the Kgp and Rgpa, adhesion domains have a similar sequence. ${ }^{13,33}$

In human $\mathrm{T}$ cells, including $\mathrm{CD} 4, \mathrm{CD} 8$, and $\mathrm{CD}$ 2, gingipain can cleave some co-stimulatory molecules, which can influence host cell-mediated immune responses to periodontopathic biofilms. An imbalance of Th1 polarization with CD4 T cells is associated with the development of periodontitis. Interferon-c levels and IL-12 were significantly increased in gingival tissue biopsy and gingival crevicular fluid from patients with periodontitis. Interferon-c and IL-12 play in regulating tissue damage and bone resorption in periodontitis. These data indicate that pro-inflammatory and anti-inflammatory Thcytokines are degraded and deactivated by gingipain, so it can cause host immune dysregulation.

Gingipain (HRgpA RgpB, Kgp) inhibits the alternative, classical, and lectin pathways that activate the complement by degrading the central complement component of C3. Inhibition of these pathways causes the complement activation $\mathrm{C} 3 \mathrm{~b}$ opsonization membrane attack complex (MAC) to be inhibited. HrgpA $P$. gingivalis protecting from the complement system by binding to $\mathrm{C} 4 \mathrm{BP}$, the $\mathrm{C} 4 \mathrm{~b}$ binding protein for inhibiting complement activation $\mathrm{C} 3 \mathrm{~b}$ opsonization MAC (Figure 2). ${ }^{34,35}$
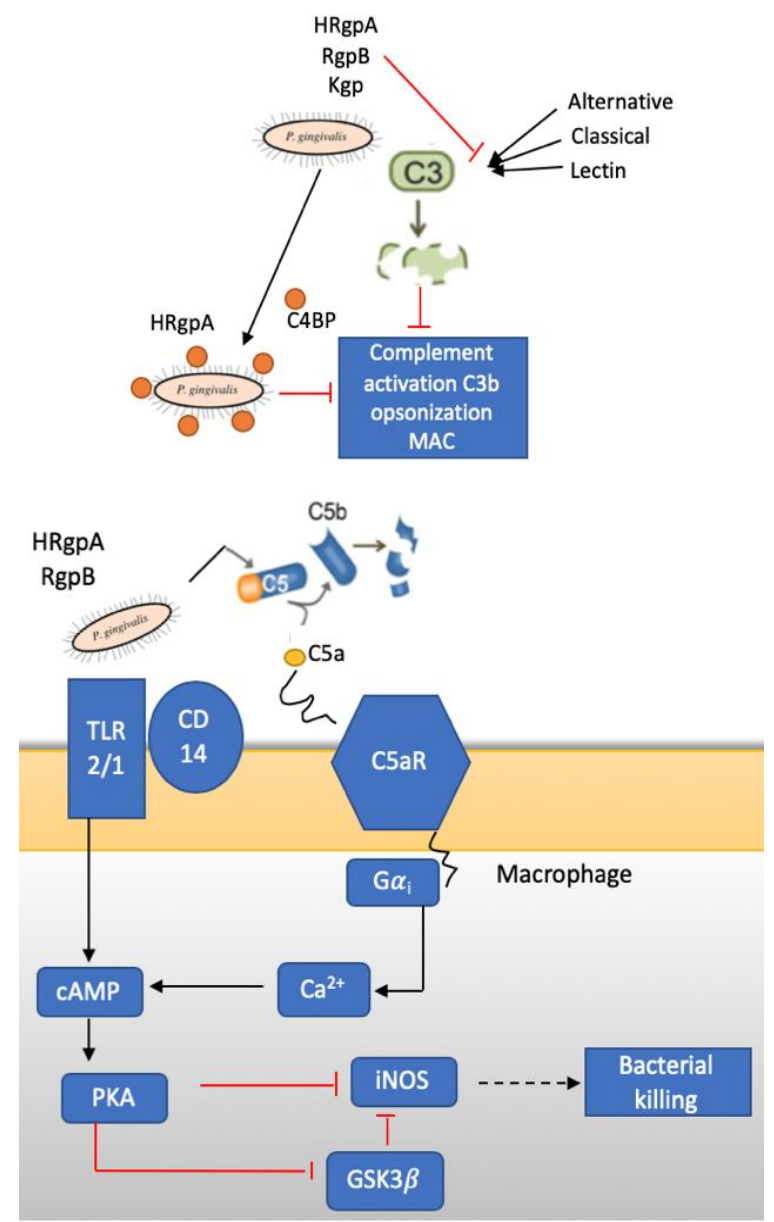

Figure 2. Role of gingipain in the manipulation of complement system ${ }^{35}$

$P$. gingivalis also interacts with TLR2 with CD14 and TLR1. Part of the TLR2 response is subverted by $P$. gingivalis through cross-talk signalling with complement receptors. HRgpA and $\mathrm{RgpB} P$. gingivalis release active C5a from C5, then actives the $\mathrm{C} 5 \mathrm{a}$ receptor $(\mathrm{C} 5 \mathrm{aR})$ in macrophages, then induce intracellular $\mathrm{Ca}^{2+}$ signalling, thereby increasing cAMP, which is also induced by TLR2 activation. The cAMP will activate protein kinase A (PKA), so it will deactivate glycolgen synthase kinase-3 $\beta$ (GSK3 $\beta$ ) and inhibit intracellular defenses that depend on iNOS in macrophages so that bacterial killing does not occur (Figure 2). ${ }^{35,36}$

\section{DISCUSSION}

In the course of evolution, $P$. gingivalis has learned to disrupt the innate defence system, for example, it will interfere with the complement system and TLRs, thus disturbing the signalling pathway. The effects of interference with the regulation of the host system will affect periodontal 
disease, whether it will develop or not. In the initial stages, decreasing the inflammatory response and avoidance of the host system will help $P$. gingivalis in colonizing, attacking and defending in the targeted location. At a later stage, $P$. gingivalis can induce inflammation to facilitate the nutritional needs required by $P$. gingivalis.

$P$. gingivalis tactics to damage innate immunity so can increase the survival of bacteria in the periodontal biofilm community. For example, the manipulation of complement by $P$. gingivalis is a strategy to provide means for other species to survive on biofilms, then to continue the opportunity to colonize and in return, the availability of nutrients for $P$. gingivalis. This capacity occurred as $P$. gingivalis bearing the virulence factors such as fimbriae, capsules, lipopolysaccharide, and gingipain. Studies show that although $P$. gingivalis exists in low quantities, this species qualitatively affects oral microbiota, which in turn has a role in bone loss induced by $P$. gingivalis. For this reason, $P$. gingivalis is a 'keystone' bacteria in subgingival biofilms.

The role of capsules as one of the $P$. gingivalis virulence factors is by suppressing the host immune response to bacteria, so phagocytosis is reduced, and the bacteria are survived. Capsules are one of the important $P$. gingivalis virulence factors because have several virulence properties, which can serve as a target for the development of therapeutic strategies. Research shows immunization of $P$. gingivalis capsules in mice stimulates the $\operatorname{IgG}$ response that reacts with all $P$. gingivalis bacteria. Furthermore, vaccination with $P$. gingivalis capsules prevents bone loss caused by P.gingivalis exposure in the murine model. ${ }^{10}$ Further research will determine the efficacy of $P$. gingivalis capsules as vaccine candidates for use in the prevention of periodontitis.

It is known that $P$. gingivalis fimbriae are highly immunogenic and immunization with purified fimbria from $P$. gingivalis 381 inhibits the progression of periodontal disease. ${ }^{37}$ Fimbriae are responsible for the adhesion and invasion of bacteria that can cause periodontal tissue damage. Some researchers have made it a vaccine candidate, because of its ability to facilitate adhesion and invasion of bacteria into tissues. Immunization of mice with $P$. gingivalis FimA which pro-

\section{REFERENCES}

1. Cekici A, Kantarci A, Hasturk H, Van Dyke TE. Inflammatory and immune pathways in the pathogenesis of periodontal disease. Periodontology 2000 2014; 64(1): 57-80.

2. Hajishengallis G. Periodontitis: from microbial immune subversion to systemic inflammation. Nature Reviews Immunology 2015; 15(1): 30-44. duces anti-FimA monoclonal antibodies through passive immunization has an activity to inhibit the binding of $P$. gingivalis to the tooth surface. Further research must be carried out to characterize the inhibitory properties of bacteria mediated by monoclonal antibodies. ${ }^{38}$

Lipopolysaccharide $P$. gingivalis gives rise to a weak immune response. Besides, $P$. gingivalis can synthesize heterogeneous populations of lipid A molecules, which differ slightly from each other in their structure. The lipid structure of $P$. gingivalis has a role in interfering with the oral immune homeostasis needed to maintain oral health, thereby increasing periodontal disease. The structure of lipid A activates immune cells selectively to induce immune responses without triggering the production of toxic mediator levels, making lipid A a good vaccine candidate. ${ }^{39}$

Gingipain is a very virulent cysteine proteinase secreted by $P$. gingivalis which causes the development of periodontitis. Gingipain decreases inflammatory cytokines thereby reducing host response by manipulating complement and disruptting $\mathrm{T}$ cell responses. Gingipain is also involved in vascular permeability. Gingipain can be a vaccine candidate to prevent periodontitis, because of its strong virulent nature. In one study, mice immunized with the RgpA DNAvaccine observed changes in cytokine levelsInterleukin (IL) -2, 4, 5 and 12 productions are found to be increased. Other studies have shown that the RgpA vaccine can induce high serum antibody levels against $P$. gingivalis. So it can be concluded that the RgpA DNA vaccine can induce cellular and humoral immune responses to protect $P$. gingivalis. Further research evaluates the protective effect of the HRgpA DNA vaccine against gingipain virulence in bone loss. The result is a significant increase in specific IgG against $P$. gingivalis. $^{40}$

$P$. gingivalis expresses several virulence factors involved in the colonization of subgingival plaque, modulates the immune response of host cells, and damages the host tissue directly so that it can cause periodontitis.

3. Van Dyke TE. Commentary: periodontitis is charac-terized by an immuno-inflammatory hostmediated destruction of bone and connective tissues that support the teeth. J Periodontol 2014; 85(4): 509-11.

4. Elburki MS. The Etiology and Pathogenesis of Periodontal Disease. BAOJ Dentistry 2018; 4:042 
5. Nazir MA. Prevalence of periodontal disease, its association with systemic diseases and prevention. International journal of health sciences 2017; 11(2): 72.

6. Abbass MMS, Rady D, Radwan IA, et al. Prevalence of periodontal diseases and its correlation with different risk factors among an adult Egyptian population: a cross-sectional study. F1000Research 2019; 8: 1-20

7. Pathirana RD, O'Brien-Simpson NM, Reynolds EC. Host immune responses to Porphyromonas gingivalis antigens. Periodontology 2000 2010; 52(1): 218-37.

8. Hajishengallis G. Immune Evasion Strategies of Porphyromonas gingivalis. Journal of Oral Biosciences 2011; 53(3): 233-40.

9. How KY, Song KP, Chan KG. Porphyromonas gingivalis: An Overview of Periodontopathic Pathogen below the Gum Line. Front Microbiol 2016; 7(53): 1-14.

10. Singh A, Wyant T, Anaya-Bergman C, et al. The capsule of Porphyromonas gingivalis leads to a reduction in the host inflammatory response, evasion of phagocytosis, and increase in virulence. Infection and immunity 2011; 79(11): 4533-42.

11. Silva N, Abusleme L, Bravo D, et al. Host response mechanisms in periodontal diseases. J Appl Oral Sci 2015; 23(3): 329-55.

12. Silva N, Abusleme L, Bravo D, et al. Host response mechanisms in periodontal diseases. Journal of Applied Oral Science 2015; 23(3): 329-55.

13. Bostanci N, Belibasakis GN. Porphyromonas gingivalis: an invasive and evasive opportunistic oral pathogen. FEMS Microbiol Lett 2012; 333(1): 1-9.

14. Zenobia C, Hajishengallis G. Porphyromonas gingivalis virulence factors involved in subversion of leukocytes and microbial dysbiosis. Virulence 2015; 6(3): 236-43.

15. Könönen E, Gursoy M, Gursoy UK. Periodontitis: A multifaceted disease of tooth-supporting tissues. Journal of clinical medicine 2019; 8(8): 1135.

16. Hasan A, Palmer R. A clinical guide to periodontology: Pathology of periodontal disease. British Dental Journal 2014; $216(8): 457$.

17. Graves DT, Kang J, Andriankaja O, Wada K, Rossa Jr C. Animal models to study host-bacteria interactions involved in periodontitis. Periodontal Disease: Karger Publishers; 2012; 15: 117-32.

18. Xu W, Zhou W, Wang H, Liang S. Roles of Porphyromonas gingivalis and its virulence factors in periodontitis. Advances in Protein Chemistry and Structural Biology 2020; 120: 45-84.

19. Kolenbrander PE, Palmer Jr RJ, Periasamy S, Jakubovics NS. Oral multispecies biofilm development and the key role of cell-cell distance. Nature Reviews Microbiology 2010; 8(7):471.

20. Nakayama K. P orphyromonas gingivalis and related bacteria: from colonial pigmentation to the type IX secretion system and gliding motility. Journal of periodontal research 2015; 50(1): 1-8.

21. Estrela CRdA, Pimenta FC, Alencar AHGd, Ruiz LFN, Estrela C. Detection of selected bacterial species in intraoral sites of patients with chronic periodontitis using multiplex polymerase chain reaction. Journal of Applied Oral Science 2010; 18(4): 426-31.

22. Brunner J, Scheres N, El Idrissi NB, et al. The capsule of Porphyromonas gingivalis reduces the immune res-ponse of human gingival fibroblasts. BMC mic-robiology 2010; 10(1): 5.

23. Enersen M, Nakano K, Amano A. Porphyromonas gingivalis fimbriae. Journal of oral microbiology 2013; 5(1): 20265.

24. Nagano K, Hasegawa Y, Yoshida Y, Yoshimura F. A major fimbrilin variant of Mfa1 fimbriae in Porphy-romonas gingivalis. Journal of dental research 2015; 94(8): 1143-48.

25. Aoki Y, Tabeta K, Murakami Y, Yoshimura F, Yamazaki K. Analysis of immunostimulatory activity of Porphyromonas gingivalis fimbriae conferred by Toll-like receptor 2. Biochemical and biophysical research communications 2010; 398(1): 86-91.

26. Takahashi M, Chen Z, Watanabe K, et al. Toll-like receptor 2 gene polymorphisms associated with aggressive periodontitis in Japanese. The open dentistry journal 2011; 5: 190.

27. Makkawi H, Hoch S, Burns E, et al. Porphy romonas gingivalis Stimulates TLR2-PI3K Signaling to Escape Immune Clearance and Induce Bone Resorption Independently of MyD88. Front Cell Infect Microbiol 2017; 7: 359.

28. Groeger S, Jarzina F, Domann E, Meyle J. Porphyromonas gingivalis activates $\mathrm{NF \kappa B}$ and MAPK pathways in human oral epithelial cells. BMC immunology 2017; 18(1): 1.

29. Hajishengallis G, Shakhatreh M-AK, Wang M, Liang S. Complement receptor 3 blockade promotes IL-12-mediated clearance of Porphyromonas gingivalis and negates its virulence in vivo. The Journal of Immunology 2007; 179(4): 2359-67.

30. Yang X, Pan Y, Xu X, et al. Sialidase deficiency in Porphyromonas gingivalis increases IL-12 secretion in stimulated macrophages through regulation of CR3, IncRNA GAS5 and miR-21. Frontiers in cellular and infection microbiology 2018; 8: 100.

31. Ogawa T, Yagi T. Bioactive mechanism of Porphyromonas gingivalis lipid A. Periodontology 2000 2010; 54(1): 71-7.

32. Kato H, Taguchi Y, Tominaga K, Umeda M, Tanaka A. Porphyromonas gingivalis LPS inhibits osteoblastic differentiation and promotes proinflammatory cytokine production in human periodontal ligament stem cells. Archives of oral biology 2014; 59(2): 167-75.

33. de Diego I, Veillard F, Sztukowska MN, et al. Structure and mechanism of cysteine peptidase gingipain $\mathrm{K}(\mathrm{Kgp})$, a major virulence factor of Porphyromonas gingivalis in periodontitis. Journal of Biological Chemistry 2014; 289(46): 32291-302

34. Krauss JL, Potempa J, Lambris JD, Hajishengallis G. Complementary Tolls in the periodontium: how periodontal bacteria modify complement and Toll- 
like receptor responses to prevail in the host. Periodontology 2000 2010; 52:141.

35. Hajishengallis G, Lamont RJ. Breaking bad: manipulation of the host response by Porphyromonas gingivalis. Eur J Immunol 2014; 44(2):328-38.

36. Wang M, Krauss JL, Domon $\mathrm{H}$, et al. Microbial hijacking of complement-Toll-like receptor crosstalk. Sci. Signal. 2010; 3(109): 1-16.

37. Choi YS, Moon JH, Park JH, Lee JY. Characterization of FimA in Porphyromonas gingivalis genotype IV. FEMS Immunol Med Microbiol 2012; 65(3): 497-500.
38. Lucchese A, Guida A, Capone G, et al. Designing a peptide-based vaccine against Porphyromonas gingivalis. Front Biosci (School Ed) 2013; 5: 6317

39. Jain S, Darveau RP. Contribution of Porphyromonas gingivalis lipopolysaccharide to periodontitis. Periodontol 2000 2010; 54(1): 53-70.

40. Jain H, Kamble P, Ahmed R. The use of gingipain DNA vaccine against virulence of Porphyromonas gingivalis: A literature review. Journal of Cell Biology and Histology 2018; 1(1): 1-4 